\title{
A Prerogative in Team Teaching: Healthcare Student's Experiential Learning
}

\author{
James Malce Alo, PhD, MAN, MAPsych, RN, OSHA \\ Imam AbdulRahman Bin Faisal University, King Faisal Road, Dammam City, Eastern Province of Dammam, \\ P.O Box 1982 Dammam, 31441, Kingdom of Saudi Arabia
}

\begin{abstract}
This study traverses the experiences with team teaching. Seek to understand the life ways of the nursing students, describe and analyze their experiences. Phenomenological description and interpretation to their experiences, related to teaching strategies experienced. It provides guidelines for the development of a more relevant school curriculum to meet the needs of the student at school. This will provide insight to the school administration offering nursing education the importance of a base hospital where students sharpen their nursing skills. This study presents an ultimate view of my experiences and students' experiences with team teaching. The value of the study rekindles on how the students felt with their experiences in school settings. For the academicians, this study introduces insights and inputs on how to nourish experiential learning with our students particularly in the medical field. Finally, the study will give adrenalin to others in doing in depth analysis of the concept and practices associated with team teaching in the parlance of nursing education where the concept has been immersed. The findings of this study suggest that nursing students recognize the significance of team teaching, in school settings. The continuing experiences of the student nurses' in a variety of experiential learning strategies, is the effective means of acquiring necessary increasing knowledge, skills, attitude and values to become an excellent nurse practitioner.
\end{abstract}

Keywords: phenomenology, lived experienced; team teaching; prerogative, learning, experiential, dyadic question, triadic question, healthcare.

\section{Introduction}

The study explored the student's experiences during their exposure with team teaching. The effort to identify their experiential learning, their description to teaching strategies used by their clinical instructors, their experiences in the school, the outcomes, and relationship of experiential learning as students were exposed to the strategies used by their clinical instructors geared towards excellent clinical nursing practice.

\section{Research Method}

The study used the phenomenological approach [1]. It was conducted in a community, college of nursing classroom, and laboratory. It documents and describes instances of student experienced that were gathered through three and a half months of videotaped observation, photo documentation and fifteen unstructured interviews. Also, the students wrote weekly journals reflecting their classroom experiences.

The research focused on the human experiences in the field of nursing education. The study has the target population of ninety-nine (99) but only fifteen (15) students were selected as co researchers. They were subjected to sampling to get their feedback using informal interviews randomly.

The reflections and observations were focused during their 3rd year level up to their 4rth year level where their experiences and activities were documented. The observations were focused and based on the purpose formulated for the study. Reflexivity, participant observation and cultural analysis were used [2]. The student's activities and experiences were made during their exposures in team teachings administer by their teachers.

\section{Results and Discussions}

The study was to explore students experience during their exposure with team teaching [3]. This is an endeavor to identify what are their experiential learning, their description, their experiences at school, the outcomes and relationship of experiential learning as students were exposed to team teaching used by their instructors geared towards excellent clinical nursing practice.

\subsection{What are the experiences of the student nurses with team teaching that constitute experiential learning?}

There are positive experiences of the student nurses with team teaching that constituted experiential learning. In Team Teaching (TT), teamwork was developed between and among student nurses. This is perceived to be effective, because it bonded them as a group and consequently, boosted their confidence. One of the students asked by the researcher to discuss the case of the patient handled the student were very confident 
telling his instructor about the case of her patient. However, team teaching did broaden, the student nurses' understanding of the nursing course; it enhances the student knowledge; hence, it improves the relationship between and among students involve in group activity. The interaction skills of the student to their client improved [4]. The critical thinking skills of student improved to the academic discourse done by teachers; camaraderie fostered among group members. Students already know how to support the ideas of their copresenter upon presenting the case of their patient during "case presentation."

\section{Students Prepare for Case Presentation}

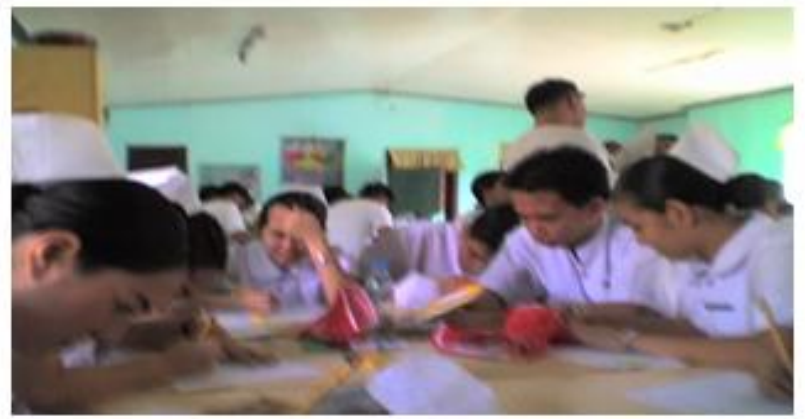

Figure 1: Group study while preparing their case presentation

In team teaching both teachers actively share the instruction of content and skills to the students, accepting equal responsibility for the education of all students and are actively involved throughout the class period [5]. As students look back over their lives they often note their watershed learning experiences- their first kiss, love, achievements and experiences, the students will have the desire to listen participate and share their point of view in the classroom. Instructors who share their experiences to give light with the concept discussed based on their personal experienced; student will easily understand and remember at times the knowledge will be needed. Expertise in the subject to be discussed is essential if the method is team teaching because you need to coordinate with the level of thinking your co presenter must avoid confusion from the students. If the strategy is properly implemented it promotes camaraderie and improve relationship to members of the team [6]. What we have in life is one great experience at best, and the reason of life is to reproduce that experience as often as possible. However, the lengthy and earnest conversation with the informant, said that, "The strategy of my teacher made me learns how to use my critical thinking skill, my mind was forced to think of the possible ideas to share, because I am inspired to participate," this is the expression of a student when asked by a teacher giving a question relevant to the concept presented. A question that will suggest analysis and critical thinking enable the student to be involved in the lesson discussion that will make the experienced unforgettable, because experience refers to the nature of events someone has undergone [7].

Experiential educators operate under the assumption that: educational goals can be effectively met by allowing the nature of learner's educational experience through practical return demonstration to let them assimilate and be influence by the educational process and are generally aware that experiences alone are not inherently good for learning [8]. Thus, experiential try to arrange sets of experiences which are conducive towards educational goals. Students could apply things learned at school in real situation and able to exercise the procedure practice in the laboratory [9]. As the student progresses in understanding the interrelatedness of the many principles and skills needed to plan and provide nursing care, continued experience in a variety of health agencies, as appropriate, and is the means of effecting increasingly skillful performance.

Nursing student's experiences of their clinical practice provide greater insight to develop an effective clinical teaching strategy in nursing education [10]. It prepares student nurses to be able of "doing" as well as "knowing" the clinical principles in practice.

\subsection{What is their description of teaching strategies used by their instructors?}

The students described the teaching strategies used by their instructors as they experienced during their 3rd and 4rth year in nursing education. It shows that, most of the students have identified and described that teamwork is very important in teaching. Teamwork and interaction with fellow nursing faculty in delivering lessons will ensure the student a rewarding experience at work in nursing environment. Therefore, team teaching gives students the opportunity of having more than two (2) teachers instead of one (1). The advantage of the team teaching approach includes: various teaching styles and activities, more time for one on one and small group instruction [11]. Interaction between teachers serves as a positive model for interaction between students, more student involvement and participation with more supervision, and more than two (2) teachers planning together to address students' needs. 
However, other students described the teaching approach used by their teachers and, it is observed that there are teacher monopolized the discussion, "there's no teamwork," the other one, once presenting the topic assigned is dependent on the ideas of her co-team teachers and displays dependency, maybe because lack of experience in the concept taught or in other words wasn't able to prepare.

Lectures required students to act as passive receptors of communicated information, but team teaching involves the student in the physical and mental stimulation created by viewing two individuals at work. It begins with the recognition that the instructor/student link is critical and offers an approach that has been shown to stimulate and provoke, while expanding and enriching student understanding. Interest in the course can be stimulated as students share the enthusiasm and intellectual discourse that the lecturers communicate. Team teaching is not boring. Students are drawn into the situation from the first moment.

The strategies of team teaching are a group of teachers working together to plan conduct and evaluate the learning activities for the same group of learners. It is simply team work between two qualified instructors who, together, make presentations to the class. Teachers using the approach of team teaching should prepare and plan to stimulate student have learning experience [12].

\subsection{How did the students view the relationship of experiential learning towards clinical nursing practice?}

The students view very significantly the relationship of experiential learning towards clinical nursing practice. In fact, the students shared how their experiential learning significantly related towards actual clinical nursing practice. Student nurses were involved in actual activities or work in clinical nursing practice. Student nurses have learned from their experience in the classroom. However, students have shared that their experiences in the classroom really help them to become effective and efficient nurse in implementing nursing interventions to their respective patient assignment. Thus, student nurse viewed very significantly the relationship of experiential learning towards clinical nursing practice.

\subsection{What are the important outcomes of team teaching that changed student nurses' life direction?}

The result shows, the nursing student will be given an opportunity to apply classroom theory to as many client/patient situations as possible to enhance their skills in nursing care. While, the student nurses could demonstrate therapeutic communication skills as they do nurse - patient interaction. Students were easily understood by their patient while providing nursing care. Students could grasp confidence, in interacting with patients during health teaching interventions to their clients. Most of the students have acquired a good level of nursing skills in performing procedures. Students' nursing knowledge increased as they possess such attribute because of the clinical instructors experience shared and it follows the other attributes: good communication, gratitude, motivation and decision-making. The students understanding the interrelatedness of the many principles and skills needed to plan and provide nursing care were develop as students were exposed in actual clinical setting and apply what they learn from school. Therefore, it is further observed by the students that they have learned additional knowledge because of the number of experienced teacher handling topics based on their specialty. It is implicated by the fact that while academic discussions perk up intellectuality, the personal interactions articulate emotionality, actual and personalize delivery of care fortify nursing skills.

The classroom is a setting where clinical instructors and students share the responsibility for creating an educational climate which fosters intellectual inquiry, critical thinking and creativity; facilitates the development of each person's potential; and reflects democratic values and ethical principles.

Undergraduate nursing education is based upon studies in the arts, sciences and humanities and provides a foundation for continuing personal, professional and educational development. The baccalaureate program is designed to prepare a competent, self-directed, general practitioner of nursing who can assume increasing responsibility and leadership in the delivery of nursing care for individuals, families, groups, communities and societies.

\section{Conclusion}

This study has provided insight into phenomenology and its value as research method that provide the means to study experiences of the nursing students. The findings of this study suggest that nursing students recognize the significance of team teaching towards excellent clinical nursing practice. The continuing experiences of the student nurses' in a variety of experiential learning strategies, is the effective means of acquiring necessary increasing knowledge, skills and values to become an excellent nurse practitioner.

\section{Acknowledgements}

The author would like to acknowledge the nursing students for their detailed and substantive information which help foremost in constructing a thematic analysis as a useful method for qualitative research in and beyond psychology. To my colleagues, for their effort and time devote on interviews. Finally, I would like to appreciate for the scientist and readers who freely give their time and made these studies possible. 


\section{References}

[1]. M. Hammersley, and P. Atkinson. Ethnography: Principles in Practice. London: Routledge, 1995

[2]. P. Atkinson, \& M. Hammersley. Ethnography and Participant Observation. In Norman Denzin and Yvonna Lincoln (Eds.), Handbook of Qualitative Research. Thousand Oaks: Sage, 2004, pp.249-261.

[3]. R. Brandenburg. Team Wise School of Knowledge: An Online Resource About Team Teaching, 2005.

[4]. H. Bulmer. Symbolic Interactionism: Perspective and method. Englewood CliffS, NJ: Prentice Hall, 2000.

[5]. K. Goetz. Independent Inquiry on the Perspectives of Team Teaching. 2006.

[6]. J.M. Alo. "Job Satisfaction and Productivity of Commission on Audit (Personnel): An Analysis," M.A. Thesis, University of Santo Tomas (UST), Philippines, 2003.

[7]. D. A. Kolb. Experiential learning: Experience as the source of learning and development. Englewood Cliffs, NJ: Prentice-Hall, 1984.

[8]. M.K. Smith. David A. Kolb on experiential learning. the encyclopedia of informal education, http://www.infed.org/b-explrn.htm. 2001 .

[9]. N. Abraham. (2005, Jan.). "Teaching with the Nightingale Tracker Technology in Community-Based Nursing Education: A Pilot Study. Journal of Nursing Education, Vol. 44, Number 1. p. 40.

[10]. A.S. Maglaya. Nursing Practice in the Community. $3^{\text {rd }}$ Edition. Published by Argonauta Corp. 2003.

[11]. S. Quinn and S. Kanter. Team Teaching: An Alternative to Lecture Fatigue. (JC 850 005) Paper in an abstract: Innovation Abstracts (Eric Document Reproductive Service No. ED 251 159), 2000.

[12]. B. Robinson and R. Schaible. Collaborative teaching: Reaping the benefits. College Teaching, 43 (2), 57-60, 2005

James Malce Alo. "A Prerogative in Team Teaching: Healthcare Student's Experiential Learning." IOSR Journal of Nursing and Health Science (IOSR-JNHS) 6.4 (2017): 38-41. 